\title{
The Impacts of Additional Automotive Tax to Selected Car Manufacturers in Metro Manila
}

\author{
Luis Isedro V. De Dios ${ }^{1}$, Renz Daniele A. Dimapilis²*iD, \\ Ronnie Dominic P. San Pedro 3 (D), Ronaldo R, Cabauatan 4 (D)
}

${ }^{1}$ College of Commerce and Business Administration, University of Santo Tomas, Manila, Philippines. Email: luiseduardo.dedios.comm@ust.edu.ph

${ }^{2}$ College of Commerce and Business Administration, University of Santo Tomas, Manila, Philippines. Email: renzdaniele.dimapilis.comm@ust.edu.ph

${ }^{3}$ College of Commerce and Business Administration, University of Santo Tomas, Manila, Philippines.

Email: ronniedominic.sanpedro.comm@ust.edu.ph

${ }^{4}$ College of Commerce and Business Administration, University of Santo Tomas, Manila, Philippines;

Research Center for Social Sciences and Education, University of Santo Tomas, Manila, Philippines;

The Graduate School, University of Santo Tomas, Manila, Philippines.

Email: rrcabauatan@ust.edu.ph

\section{CORRESPONDING}

AUTHOR (*):

Renz Daniele A. Dimapilis

(renzdaniele.dimapilis.comm@ust.edu.ph)

KEYWORDS:

Tax reform

Car manufacturers

TRAIN law

Automobile

Total unit sales

\section{CITATION:}

Dios, L. I. V. D. D. et al. (2022). The Impacts of Additional Automotive Tax to Selected Car Manufacturers in Metro Manila. Malaysian Journal of Social Sciences and Humanities (MJSSH), 7(2), e001312. https://doi.org/10.47405/mjssh.v7i2.1312

\section{ABSTRACT}

The implementation of the Tax Reform for Acceleration and Inclusion Law (TRAIN) caused several adjustments across various industries including the automobile business. This study was conducted to determine the total unit sales of automobiles of selected car manufacturers in Metro Manila a year before and after implementing the TRAIN law; identify the effect of change in retail price on the total sales; and determine the impact of competition to the total sales The study employed a descriptive research design. A total of twenty-five purposively chosen key respondents were included in the study. Five high-ranking management members from each brand with local manufacturing operations in the Philippines namely, Toyota, Mitsubishi, Foton, Honda, and Nissan were the respondents. The data was collected through the use of online survey questionnaires and were analyzed using descriptive statistics (mean, standard deviation, etc.), frequencies, and percentage. There was a significant effect on the automotive industry in the Philippines brought by the implementation of the TRAIN law. It was found out that the total unit sales of the five selected car manufacturers have decreased during the year of implementation of the additional automotive tax compared to their sales prior to the year of its actual implementation. These car manufacturers have also adjusted their retail price necessitated by the TRAIN law, which also affected their total sales. Competition between the leading car manufacturers in the country was also taken into account. It was found out that there was a high level of competition among car companies. 
Contribution/Originality: This study contributes in the existing literature by considering different variables that affects the total unit sales of a car manufacturing company such as the added excise tax, change in retail price, and the presence of competition. This article also discusses the degree of impact that the TRAIN law had posed to the selected car manufacturers.

\section{Introduction}

Countries implement tax reforms to stimulate the economy and elevate their citizens' way of life. On January 1, 2018, the Tax Reform for Acceleration and Inclusion Law or TRAIN took effect. The law adjusted the income tax policy provisions by setting the minimum taxable annual income at 250,000 pesos. It shifted to an increased tax on other non-necessary commodities such as automobiles, alcohol, tobacco, and sugary foods (National Tax Research Center, 2018). One of the industries affected by the tax reform is the automobile industry. In 2017, a year before implementing the law, the automotive industry sold over 473.9 thousand automobile units. It was then followed by a $15 \%$ dip in sales in 2018 at 401.8 thousand units and was considered the first dip in the automobile industry's growth in 8 years in the Philippines (International Trade Administration, 2020). The decreasing trend continued in 2019, where only 273.4 thousand units were sold (Sanchez, 2020).

Countries like China and Ireland implemented several tax policies to regulate the environmental impacts of automobiles. In China, three tax adjustments have been implemented to divert consumer choice to more green automobile choices (Xi \& Yun, 2014). The laws successfully shifted the direction of car sales towards greener alternatives. However, it came with social welfare issues like an increased fare for commuters and the burden of tax payment for business owners (Xi \& Yun, 2014). In Ireland, on the other hand, a taxation model has been created based on the fuel displacement of automobiles. The law successfully changed the preferences of the Irish automobile consumers; however, it decreased the state's tax income as people chose to purchase cars with smaller tax costs (Hennessy \& Tol, 2011). Different outcomes for several countries can be used to compare the consequences of the Philippines' tax policies and provide insights for improving taxation and the development of the automobile market (Reside \& Burns, 2021).

The effects of taxation affect a business in several ways. It directly impacts a company's income, thus affecting its overall operations (Dizon, 2021). The changes in a business entity's process then cause changes to its stakeholders, including its employees, stockholders, and customers, thus, the need to determine the specific changes caused by the taxation law to the particular business industry (Ebrahim, Mojares, \& Montes, 2020).

Understanding the impact of tax reform is critical in developing a country. Thus, this study aims to understand the implications of the increase in taxation caused by the Tax Reform for Acceleration and Inclusion Law (TRAIN) on the business sector, specifically in the automotive industry (Kaiser, Bredenkamp, \& Iglesias, 2016). Additionally, this study will also assess the effect of change in retail price and competition to the selected automobile manufacturers in Metro Manila.

Thus, this study attempts to determine the impacts of tax reform on the automobile industry's macroeconomy. It also aims to add to the existing knowledge about the effects 
of the Tax Reform for Acceleration and Inclusion Law (TRAIN) on the business sector and contribute to the development of the economy, business, and society. Also, the study aims to give light to future studies concerning business tax in the Philippines.

Lastly, this study will be conducted with car manufacturers in Metro Manila. The research will be focusing on the top management members of automobile companies, specifically those who have been with the company from 2017 to the present, to ensure the knowledge of business operations before and after implementing the TRAIN Law. The study will be using both primary and secondary sources such as related literature and databases related to the topic.

\section{Objectives of the Study}

Generally, this study aims to determine the impact of automotive tax on car manufacturers in Metro Manila. Specifically, the study seeks to:

i. Determine the total number of units sold of automobiles of selected car manufacturers in Metro Manila a year before and after implementing the TRAIN law;

ii. Identify the effect of change in retail price in real value to the total number of units sold of automobiles by selected car manufacturers in Metro Manila; and

iii. Determine the impact of competition on the total number of units sold of automobiles of selected car manufacturers in Metro Manila.

This study attempts to determine the impacts of tax reform on the automobile industry's macroeconomy. It also aims to add to the existing knowledge about the effects of the Tax Reform for Acceleration and Inclusion Law (TRAIN) on the business sector and contribute to the development of the economy, business, and society. Lastly, the study aims to give light to future studies concerning business tax in the Philippines.

This study will be conducted with car manufacturers in Metro Manila. The research will be focusing on the top management members of automobile companies, specifically those who have been with the company from 2017 to the present, to ensure the knowledge of business operations before and after implementing the TRAIN Law. The study will be using both primary and secondary sources such as related literature and databases related to the topic.

\section{Literature Review}

\subsection{Automotive Industry in the Philippines}

One of the industries directly affected by the changes caused by the TRAIN Law is the automobile industry. The Philippines is ranked 9 in the automobile market across the Asia Pacific region, with 273.4 thousand passenger cars sold in 2019 (Sanchez, 2020; Ofreneo, 2016). As of 2018, automotive vehicle owners' distribution is divided into motorcycle/tricycle with $25.9 \%$, while $5.9 \%$ owned multi-passenger vehicles such as cars, vans, and jeepneys (Sanchez, 2020). Sales of automotive vehicles are declining from 473.9 thousand units sold in 2017 and 401.8 thousand in 2018, resulting in a decline of 15\% (International Trade Administration, 2020). 
In many countries worldwide, the automotive industry has an iconic image, and governments frequently use it to produce economic opportunities for local constituents (Sturgeon et al., 2016; Carmudi Philippines, 2016). Over the past 50 years, the Philippines have taken that approach, with the government undertaking various policies to develop the industry. The Comprehensive Automotive Resurgence Strategy (CARS) program, which began in 2015 , is the most recent effort to boost domestic car manufacturing and build a solid supply base in the country (Government of the Philippines, 2015).

The automobile industry is a crucial player in industrialization. A study conducted by Tai (2016) about the ASEAN countries' automobile industry, namely Malaysia, Indonesia, Thailand, and the Philippines, argued that the automobile industry's development varied because of the countries' unstable political economy. In other words, a booming automobile market may lead to industrialization, but the political economy needs to be taken into consideration (Tai, 2016). During the 1980s, the Philippines missed the chance to develop its automobile industry due to the limitations imposed by the local capitalists that dominated the trade (Tai, 2016). Despite being one of the fastestgrowing economies in the ASEAN, the Philippine automobile industry fell behind as we failed to participate in the growing automobile production market (Tai, 2016). At present, imported products dominate the country's automobile trade, and there is a need to align industrialization goals (Tai, 2016).

\subsection{Car Sales and the TRAIN Law}

According to Sanchez (2020), before implementing TRAIN law, the total sales volume of vehicles in the Philippines in 2016 amounted to about 402.54 thousand units and 467.2 thousand units in 2017. The leading automotive company in the Philippines was Toyota, with approximately 182.7 thousand units sold in 2017 (Department of Finance, 2018).

According to the report of Chamber of Automotive Manufacturers of the Philippines, Inc. (CAMPI) and the Truck Manufacturers Association (TMA), the domestic motor vehicle industry's sales dropped by $16 \%$ in 2018, the worst performance since the Asian financial crisis (Crismundo, 2020). On the other hand, Cahiles-Magkilat (2019) reported that the industry, which has grown at a $16 \%$ annual rate since 2010 , or for the last eight years, was only able to sell 357,410 units in 2018, compared to 425,673 units in 2017, with all categories save trucks and buses in the red (Category IV). The much-anticipated seasonal December sales rush did not materialize, even though sales began to rebound in the second semester (Castillo et al., 2019; Cahiles-Magkilat, 2019).

The passenger car segment suffered the most, with sales falling by $21 \%$ to 109,020 units from 139,424 units in 2017. The commercial vehicle category, which accounted for $62.25 \%$ of overall sales, had a $13.2 \%$ drop from 286,249 to 248,390 units (CahilesMagkilat, 2019). In terms of commercial vehicle classifications, Asian Utility Vehicles (AUV) sales dropped the most, dropping 39.6\%, to 48,271 units in 2018, compared to 79,886 units in 2017. Light Commercial Vehicle (LCV) or Sports Utility Vehicle (SUV) sales fell by $2 \%$ to 185,430 units, down from 189,248 units the previous year (AutoDeal, 2018; Castillo et al., 2019).

Light trucks or pickups saw a substantial 22.9\% drop from 9,888 units in 2017 to 7,619 units in 2018. Category IV trucks and buses were only positive, which increased by $4.8 \%$ 
to 5,076 units from 4,845 last year (Castillo et al., 2019; Cahiles-Magkilat, 2019). The number of heavy trucks and buses (Category 5) fell by $16.3 \%$ to 1,994 units, down from 2,382 the previous year. The combined CAMPI-TMA analysis also revealed that the much-anticipated increase in December sales did not offset the year's significant reductions in the first half. Only 31,945 units were sold in December, which is only 2.2\% more than the previous month's sales of 31,258 units (Cahiles-Magkilat, 2019; Danao, 2018).

Additionally, in November 2018, passenger car sales climbed by only $1.13 \%$ to 9,301 units, compared to November of the previous year. It could not compare to the $34.4 \%$ drop in December 2017. Commercial vehicle sales increased by only $2.6 \%$ to 22,644 units from 22,061 units the previous month. It was 27.7\% lower than in December 2017. All other categories fell, with heavy trucks down 51.3\%, Asian Utility Vehicles 45.3\%, LCVs, Category 4 trucks, and buses falling $23 \%$. Only $1.7 \%$ of the reduction was due to light trucks or pickup trucks (Cahiles-Magkilat, 2019).

The usual top brands were in negative sales territory in terms of ranking, but Nissan Philippines, Inc. managed to slip into the third position with a spectacular gain of $39.8 \%$. Nissan sold 34,952 vehicles in 2018, up from 24,994 in 2017. The country's largest car manufacturer, Toyota Motor Philippines, had sales fall $16.8 \%$ to 153,004 units in 2018, down from 183,908 units in 2017, while Mitsubishi Motors Philippines had sales fall 8.3\% to 67,512 units, down from 73,590 units in 2017 (Robles, 2019). Ford Motor Company Philippines, Inc. came in the fourth position with 23,571 units sold, down 35.6 percent from its total sales of 36,623 units in 2017 (Castillo et al., 2019; CahilesMagkilat, 2019; Robles, 2019).

\subsection{Relationship of Retail Price and Overall Sales}

According to Pornelos (2017), the anticipated increase in automotive taxes in 2018 sparked a veritable buying spree as people purchased ahead to avoid paying higher taxes. Industry executives have corroborated this since their inventories have been substantially sold off, especially the more costly models like executive automobiles, premium sedans, and huge SUVs.

Pricing is one of the essential factors since it is the sole element that generates revenue for the company (Amirul, Islaini, \& Nayan, 2020). Pricing may also be used as a competitive weapon (Afif, Razak, \& Nayan, 2020) to assist a company takes advantage of market possibilities (Yussoff \& Nayan, 2020). Because pricing influences how buyers perceive a product or service, it must be consistent with the other components (Rosli \& Nayan, 2020). Price is unquestionably the most critical element affecting client purchasing decisions. Most buyers prioritize price over value at the time of purchase (Ruzanna, Baharin, \& Nayan, 2020). In other words, buyers frequently feel that higherpriced items have more excellent value and usefulness than lower-priced products (Azahari, \& Nayan, 2020). As a result, a change in pricing impacts demand, sales volume, and market share (Izarul, Syed, \& Nayan, 2020). Hence, the price frequently shapes the image of the product.

Furthermore, this aspect has several functions and determinants, one of which is the appropriate pricing (Jamaluddin \& Esa, 2020). A poor price selection might precipitate a company's demise. It is critical to set pricing at the correct level after thorough market 
research and examination of factors such as rivals' tactics, market circumstances, and manufacturing costs (Izarul, Syed, \& Nayan, 2020). Low pricing may initially attract clients, but it would be challenging for the firm to raise prices at a later period. On the other hand, very high pricing will result in higher profit margins but lower sales. As a result, it is critical to set the correct pricing to maintain a balance between profitability and sales volume (Jamaluddin \& Esa, 2020). After that, the price provides the initial impression. While a customer's final purchasing choice may be based on its overall advantages, they are more likely to assess it by comparing the price to the product's perceived worth. Customers want to know more about the product attributes after knowing about the price (Jamaluddin \& Esa, 2020). A client may lose interest in learning more about a product if it is priced too expensive, but if he believes it is reasonable, he will attempt to discover more about it. Therefore, pricing is an essential element in a buyer's choice (Amirul, Islaini, \& Nayan, 2020). Finally, there is the crucial price of sales promotion. The marketing manager may lower the cost to promote more sales. If the demand for a product is price sensitive, even a minor price drop will increase sales volume. On the other hand, prices should not be changed too frequently to promote sales (Jamaluddin \& Esa, 2020). There are numerous elements to consider and a great deal of uncertainty as to whether a price adjustment would have the desired effect (Conazo, 2018). According to the law of demand, the higher the price, the lower the demand for almost all commodities (Zamry \& Nayan, 2020). In other words, if prices are raised, sales will decrease. On the other hand, higher costs might bring higher sales (Jamaluddin \& Esa, 2020).

\subsection{Effect of Competition on Total Sales of Automobiles}

The global automobile industry is intensely competitive (Nkomo, 2019). Automobile manufacturers compete fiercely for market share. In view of continued globalization and consolidation in the global automobile sector, rivalry among various automotive companies is anticipated to heat up. Product quality and features, the length of time necessary for invention and development, price, dependability, safety, fuel economy, customer service, and financing conditions are all variables that influence competitiveness. Increased competition may result in fewer car unit sales and huge inventories, putting downward price pressure on the company's financial situation and operating results (Nkomo, 2019).

Competition in the marketplace refers to an environment in which different enterprises offer competitive products and services. These businesses attempt to increase market share and attract customers by improving price, quality, and service. Competition improves market efficiency, which translates into lower prices for goods and services. Competition forces firms to enhance their productivity, ingenuity, and responsiveness to compete for consumers (Philippine Competition Commission, 2017).

The number of companies and degree of concentration impact competition, but so do the degree of openness to trade and the regulations in place (Aldaba, 2007). Market defects such as abuse of dominant position and other anti-competitive corporate activities, as well as trade obstacles and government restrictions, restrict market entrance, resulting in inefficiencies and lower long-term growth. These factors stifle competition and hinder structural reforms, resulting in resources being linked to lowproductivity businesses (Aldaba, 2008). Weak competition decreases the pressure on companies to embrace new technology and innovate, resulting in low productivity 
growth and a loss of competitiveness. It is also worth noting that the larger environment in which businesses operate has an impact on competition. This is referred to as the "competitive infrastructure" by Carlin and Seabright (2000), including communications, financial and fiscal systems, and regulatory limitations. Aldaba (2003) investigated how the Philippine manufacturing industry performed and how competitive it was following liberalization in the 1980s and 1990s. For the years 1988, 1994, and 1995, Aldaba (2003) found that the average four company concentration ratio remained high following trade liberalization. During the same years under consideration, pricing cost margins also grew. The results indicated a positive association between concentration and profitability using a standard regression specification of the concentration-profits relationship. According to the author, this positive association is compatible with both the structuralist school and the efficiency hypothesis (Aldaba, 2008).

Given the importance of evaluating the country's political economy related to the automobile industry, the impacts of the TRAIN law, retail prices, and competition to the total sales of selected automobile manufacturers also need to be studied. A tax increase on the car manufacturers, their stakeholders, and the whole automotive industry are yet to be determined. This gap needs to be addressed to understand further the country's tax reform law's macroeconomic and macroeconomic impacts.

\subsection{Simulacrum}

The Tax Reform for Acceleration and Inclusion Law (TRAIN) aims to distribute its wealth by reformatting its tax system. The industries directly affected by the said law include alcohol, food manufacturing, tobacco, and the automobile industry. The study aims to determine the impacts of the additional tax imposed by government policies in the automobile industry.

Specifically, it seeks to answer the following questions:

i. What is the total number of units sold of car manufacturers in Metro Manila a year before and after implementing the TRAIN law?

ii. What is the effect of the change in retail price in real value on the total number of units sold of automobiles by selected car manufacturers in Metro Manila?; and

iii. What is the effect of competition on the total number of units sold of automobiles of selected car manufacturers in Metro Manila?

Figure 1 depicts the relationship of total unit sales of car manufacturers to three (3) other variables such as the TRAIN law, the change in retail price, and the impact of competition. 
Figure 1: Study simulacrum

Tax Reform for Acceleration and Inclusion (TRAIN) Law

Change in retail price in real value

\section{Methodology}

\subsection{Research Design and Instrument}

The study used a descriptive research design to determine the impact of additional automotive tax on car manufacturers in Metro Manila. The primary tool used in this study is an online survey questionnaire through Google Forms that was disseminated to the potential participants, the car manufacturers in Metro Manila.

\subsection{Participants}

The study participants were twenty-five (25) purposively selected respondents who are the top management members of the chosen car manufacturers in the Philippines, namely Toyota, Mitsubishi, Foton, Honda, and Nissan. All four car brands have manufacturing operations in the Philippines. The researchers sent online survey questionnaires to five (5) officials of each car manufacturer.

\subsection{Data Collection and Sampling}

The primary data that this study utilized is the gathered information through the online survey questionnaires provided by the researchers. The researchers have used different materials such as books, journals, articles, and online information as secondary data sources to determine the condition and method employed in the study.

Before the collection of data, permission to conduct a survey will be secured from the thesis adviser. The researchers will also be doing a permission letter for every respondent. Before the actual distribution of online survey questionnaires, the researcher will first conduct a participating pre-test through Google Forms, wherein respondents are informed about a practice run of the survey questionnaire and will be asked to give comments and suggestions on the online survey questionnaire. 
Upon the gathering of data, the researchers conducted online surveys to the participants that are involved in the study through the use of Google Forms. This has helped the researchers to gather all the necessary information that they need. Before administering the survey instrument, the respondents were assured of their confidentiality and anonymity of the information they provided. The link of the online survey questionnaire through Google Forms was sent to the managers of the selected car manufacturers in the Philippines. The duration of the survey in days depended on the progress of the respondents until the target number of respondents is reached. The researchers collated the results for analysis and interpretation.

The study employed purposive sampling and was conducted online due to interaction restrictions caused by COVID-19.

car manufacturer $=80+\beta 1 \mathrm{TRAIN}+e$

change in total unit sales $=80+81$ TRAIN $+e$

change in retail price $=80+81$ competition $+e$

car manufacturers $=80+81$ change in total unit sales $+e$

\subsection{Data Analysis}

After the researcher finishes the collection of data, all online survey questionnaires will be reviewed. Incomplete surveys will be removed and will not be included in data analysis. The data will then be analyzed through a series of statistical treatments such as descriptive statistics (mean, standard deviation, etc.), frequencies, and percentage to determine the following objectives of the study: determine the total sales of automobiles of selected car manufacturers in Metro Manila a year before and after implementing the TRAIN law; identify the effect of change in retail price to the total sales of automobiles by selected car manufacturers in Metro Manila; and determine the impact of competition on the total sales of automobiles of selected car manufacturers in Metro Manila.

Descriptive statistics. This is used to describe the essential characteristics of the data in a specific study. In this study, frequency-percentage, measures of central tendency (e.g., mean, median), and measures of dispersion (e.g., range, standard deviation) will be used to determine the impact of additional automotive tax on car manufacturers in Metro Manila.

\section{Result and Discussion}

\subsection{Demographic Profile}

Table 1 presents that there was a total of twenty-five (25) participants surveyed for this study. Among the respondents, $36.00 \%$ are of the cohort $36-40$ years old and there were only one (1) respondent from each age group of 51-55 and 56 above. It is also presented in the above table that the number of male respondents surveyed was significantly higher compared to the frequency of female participants. It could be implied that male individuals hold the majority of high-ranking and administrative positions in the car manufacturing companies involved in this study. 
Table 1: Demographic Profile of the Respondents

\begin{tabular}{llll}
\hline Characteristics & Frequency $\mathbf{N}=\mathbf{2 5}$ & Percentage \\
\hline AGE & & \\
& $30-35$ & 4 & $16.00 \%$ \\
& $36-40$ & 9 & $36.00 \%$ \\
& $41-45$ & 6 & $24.00 \%$ \\
& $46-50$ & 4 & $16.00 \%$ \\
& $51-55$ & 1 & $4.00 \%$ \\
& 56 above & 1 & $4.00 \%$ \\
SEX & Total: & 25 & $100.00 \%$ \\
& Male & 18 & $72.00 \%$ \\
& Female & 7 & $28.00 \%$ \\
\hline \multicolumn{2}{c}{ TOTAL } & 25 & $100.00 \%$ \\
\hline
\end{tabular}

\subsection{Selected Car Manufacturers}

Table 2 shows the selected car manufacturers that has local business operations in the Philippines, specifically in Metro Manila. The researchers opted to have an equal number of participants from the five (5) chosen car companies in order to have fair responses and equal chances.

Table 2: Selected Car Manufactures

\begin{tabular}{lll}
\hline Company & Frequency $\mathbf{N = 2 5}$ & Percentage \\
\hline Tovota & 5 & $20.00 \%$ \\
Foton & 5 & $20.00 \%$ \\
Nissan & 5 & $20.00 \%$ \\
Mitsubishi & 5 & $20.00 \%$ \\
Honda & 5 & $20.00 \%$ \\
\hline TOTAL & 25 & $100.00 \%$ \\
\hline
\end{tabular}

\subsection{Current Positions of the Respondents}

Table 3 shows the positions currently holds by the participants at their respective car manufacturing companies. Among the job positions of the respondents, the position of Branch Manager got the highest response corresponding to $16.00 \%$ of the total participants. It is also noticeable that the participants surveyed have a highly-diverse job positions.

Table 3: Current Positions of the Respondents

\begin{tabular}{lll}
\hline Characteristics & Frequency N=25 & Percentage \\
\hline Sales and Marketing Officer & 1 & $4.00 \%$ \\
Branch Manager & 4 & $16.00 \%$ \\
Sales Officer/Specialist/Supervisor & 3 & $12.00 \%$ \\
Financial/Profit Planning and Analysis & 3 & $12.00 \%$ \\
Accounting supervisor & 2 & $8.00 \%$ \\
Operation Head & 2 & $8.00 \%$ \\
Purchasing Officer & 1 & $4.00 \%$ \\
Field Sales Associate & 2 & $8.00 \%$ \\
Marketing and Process Specialist & 1 & $4.00 \%$ \\
Senior Staff & 1 & $4.00 \%$
\end{tabular}




\begin{tabular}{lll} 
Marketing Professional & 2 & $8.00 \%$ \\
Internal Auditor & 1 & $4.00 \%$ \\
Business Analyst Head & 2 & $8.00 \%$ \\
\hline TOTAL & 25 & $100.00 \%$ \\
\hline
\end{tabular}

\subsection{Years of Service in the Company}

Table 4 presents the length of service of the respondents at their current car manufacturing companies. The options "7-9 years" and "10-12 years" got an equal number of responses of 8 each. It could be connoted that almost all of the participants have already been with their respective companies for more than 7 years. Hence, the respondents were already working with the company way before the TRAIN law was implemented.

Table 4: Years of Service of the Respondents

\begin{tabular}{lll}
\hline Years of Service & Frequency $\mathbf{N = 2 5}$ & Percentage \\
\hline Less than a year & 0 & $0.00 \%$ \\
1-3 years & 0 & $0.00 \%$ \\
4-6 years & 2 & $8.00 \%$ \\
7-9 years & 8 & $32.00 \%$ \\
10-12 years & 8 & $32.00 \%$ \\
13-15 years & 3 & $12.00 \%$ \\
More than 15 years & 4 & $16.00 \%$ \\
\hline TOTAL & 25 & $100.00 \%$ \\
\hline
\end{tabular}

\subsection{Total Unit Sales}

Figure 2 presents the trend of the total sales of the car companies in terms of the number of units sold from a year before (2017) the implementation of the TRAIN law up to a year after (2019) its implementation.

Figure 2. Total Number of Units Sold of Car Manufacturers from 2017-2019

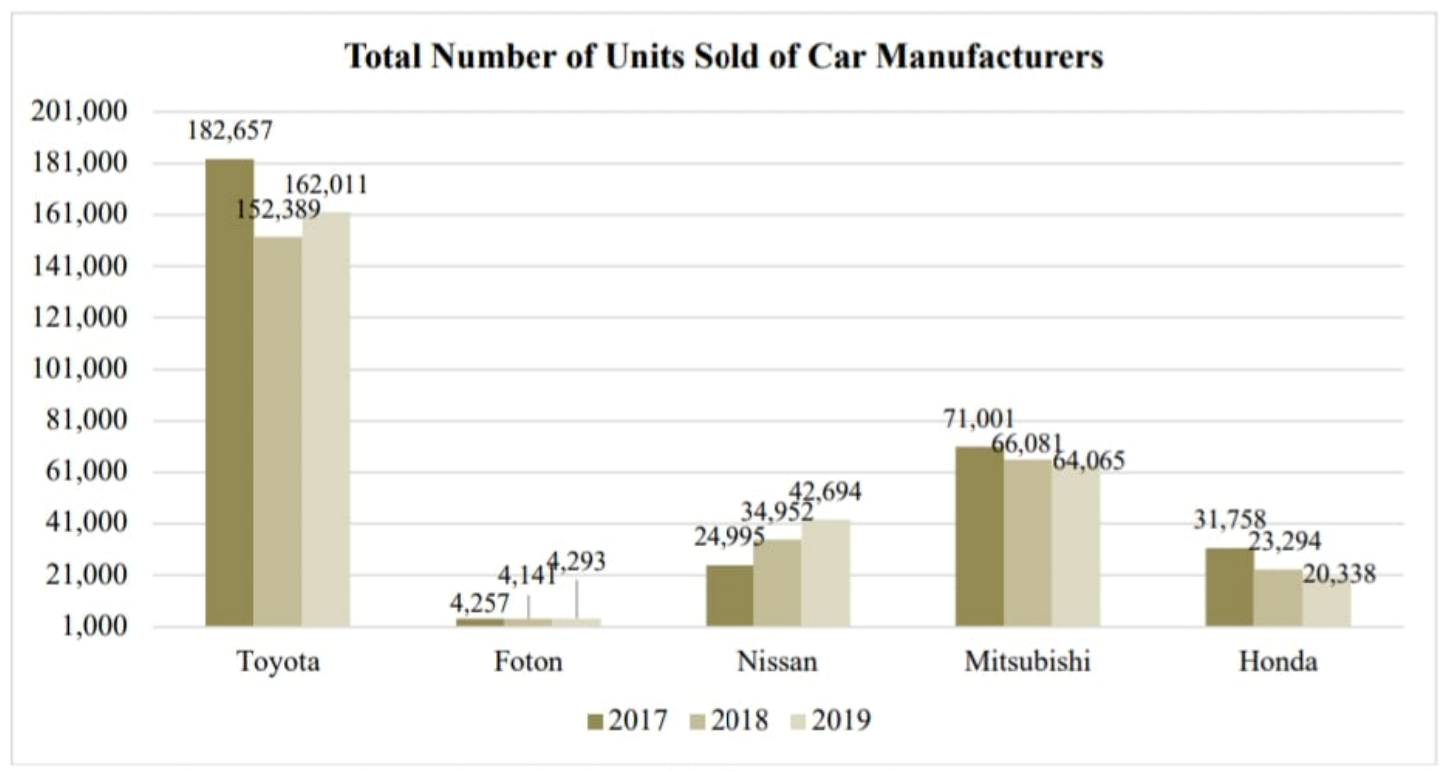


According to Sanchez (2020), before TRAIN law took into place, the total sales volume of vehicles in the Philippines in 2016 amounted to about 402.54 thousand units and 467.2 thousand units in 2017. The leading automotive company in the Philippines was Toyota, with approximately 182, 657 thousand units sold in 2017, as can be seen in the graph above.

When the TRAIN law was implemented, the usual leading car brands were in negative sales territory in terms of ranking. Nevertheless, it can be noticed that Nissan Philippines, Inc. managed to slip into the third position with a spectacular gain in 2018. Nissan sold 34,952 vehicles in 2018, up from 24,995 in 2017. The country's largest car manufacturer, Toyota Motor Philippines, had sales fall $16.8 \%$ to 152,389 units in 2018, down from 182,657 units in 2017, while Mitsubishi Motors Philippines had sales fall $8.3 \%$ to 66,081 units, down from 71,001 units in 2017 (Robles, 2019). Among the five selected car manufacturers, Honda Philippines Inc. came in the fourth position with 23,294 units sold in 2018, a decrease from its total sales of 31,758 units in 2017 (Chamber of Automotive Manufacturers of the Philippines, Inc., 2019; Castillo et al., 2019; Cahiles-Magkilat, 2019; Robles, 2019).

It can be discerned form the figure that in 2019, a year after TRAIN law implementation, three (3) car companies have seemed to been recovered from TRAIN law's impacts and posed an increase in their total sales. These companies are Toyota, Foton, and Nissan. On the other hand, the decreasing trend of sales of Mitsubishi and Honda is strongly distinguishable and evident. This may be due to adjustment in retail price, competition, and unaccounted factors.

\subsection{Company's Adjustment in Retail Price}

Table 5 shows the responses of the respondents to the question "Did your company adjust the retail price of automobiles when the TRAIN law was implemented?". All respondents attested that their respective car manufacturing companies adjusted their retail price due to TRAIN law.

Table 5: Company's Adjustment in Retail Price as Perceived by the Respondents

\begin{tabular}{lll}
\hline & Frequency & Percentage \\
\hline Yes & 25 & $100.00 \%$ \\
No & 0 & $0.00 \%$ \\
TOTAL & 25 & $100.00 \%$ \\
\hline
\end{tabular}

Automobile prices have been adjusted in compliance with the guidelines and provision of the TRAIN law (Jimeno, 2018). "Enhance the progressivity of the tax system" and providing "equitable relief to a vast number of tax payers and their families... to boost the levels of disposable income and promote economic activity" are two of the stated objectives of the TRAIN law. In a "progressive" tax system, the tax rate rises in tandem with the growth of the revenue base. Individuals that are able or have the resources to pay more taxes are disproportionately affected by this kind of system, such as the wealthy or high-income earning individuals). The TRAIN Law's "inclusion" or "inclusive" provision strives to guarantee that the country's poor and middle-class residents may take advantage of economic growth's positive effects on their lives (Jimeno, 2018). 


\subsection{Effect of Change in Retail Price in Total Sales}

Figure 3 shows the perception of the respondents regarding the relationship of retail price and total sales. Majority of the participants (56\%) responded that when the automobile retail price was changed, the total sales decreased. This reflects what happened to numerous car manufacturing companies - their total sales decreased when they adjusted their retail price due to higher tax rates necessitated by TRAIN law. The Chamber of Automotive Manufacturers of the Philippines, Inc. (CAMPI) and the Truck Manufacturers Association (TMA) reported that the sales of passenger car and commercial vehicle segments both dropped in 2018.

Figure 3: Effect of Change in Retail Price in Total Unit Sales

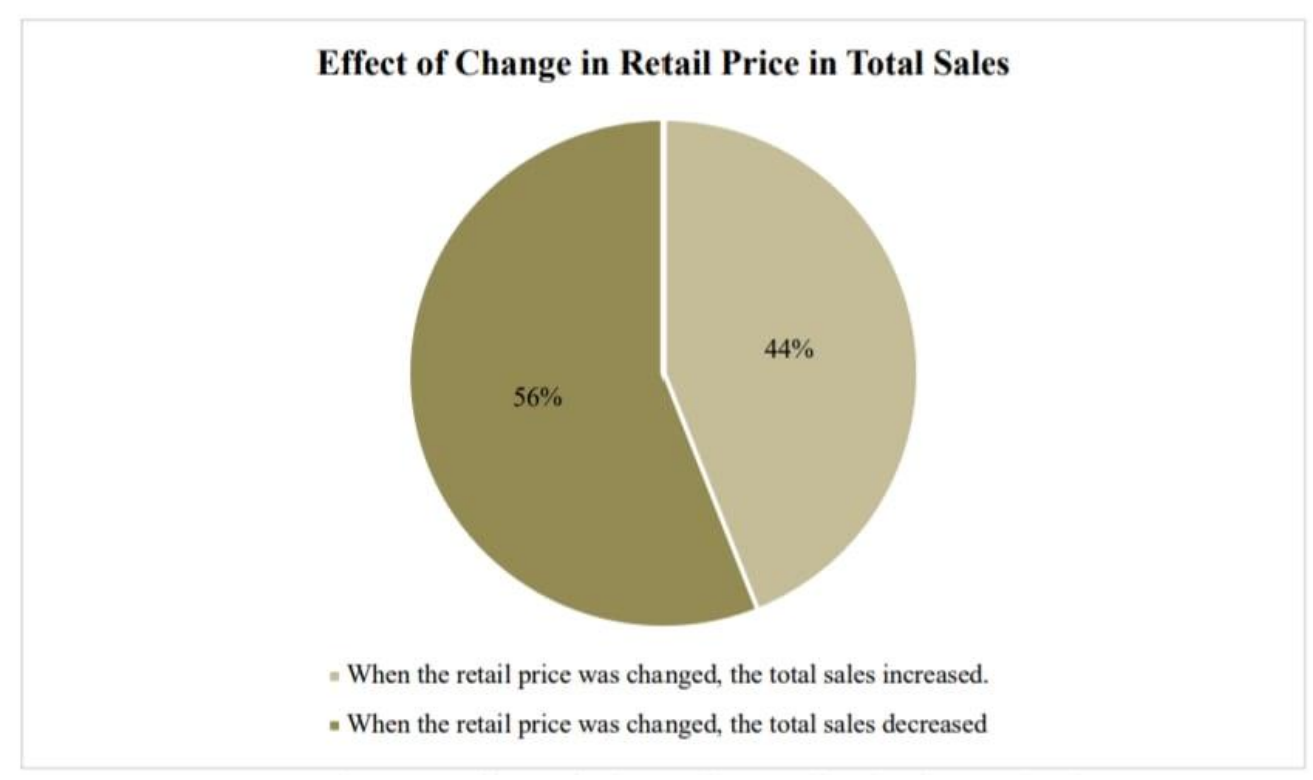

\subsection{Competition}

Table 6 shows the weighted mean of respondents' perception regarding the presence of competition among car manufacturing companies. Competition was rated based on whether: their company was threatened to other top car manufacturing companies, their automobiles have better quality and features compared to their competitors, their loyal customers stayed with them even if retail price was altered, they believe that due to competition in the automobile industry, putting downward price pressure on the company's financial situation and operating results is the best option; and if their company continuously enhances their productivity, ingenuity, and responsiveness to compete for consumers.

The students gave a unifying perception on the presence of competition among car companies. The item "Our company continuously enhances our productivity, ingenuity, and responsiveness to compete for consumers" has a weighted mean of 3.88 which indicated that they strongly agree with the statement.

Their belief that their company's automobiles have better features and quality compared to other car companies also got a relatively high response with a mean 3.68 that corresponds to strong agreement of most respondents with the statement. 
Table 6: Competition among Companies as Perceived by the Respondents

\begin{tabular}{lll}
\hline Statement & Mean & Interpretation \\
$\begin{array}{l}\text { After the implementation of the TRAIN law, our } \\
\text { company was threatened to other top car } \\
\text { manufacturing companies in the country. }\end{array}$ & Strongly Agree \\
$\begin{array}{l}\text { Our company's automobiles have better quality } \\
\text { and features compared to that of our }\end{array}$ & Strongly Agree \\
$\begin{array}{l}\text { competitors. } \\
\begin{array}{l}\text { Our loyal customers stay with us even if there } \\
\text { has } \\
\text { been a change in retail price. }\end{array}\end{array}$ & Strongly Agree \\
$\begin{array}{l}\text { Due to competition in the automobile industry, } \\
\text { putting downward price pressure on the } \\
\text { company's financial situation and operating } \\
\text { results is the best option. }\end{array}$ & 2.92 & Agree \\
$\begin{array}{l}\text { Our company continuously enhances our } \\
\text { productivity, ingenuity, and responsiveness to } \\
\text { compete for consumers. }\end{array}$ & 3.88 & \\
\hline \begin{tabular}{l} 
TOTAL \\
\hline
\end{tabular} & 3.41 & Strongly Agree \\
\hline
\end{tabular}

The overall average weighted mean is 3.41 . This means that the participants "strongly agree" with the given statements. This high level of competition among car companies entails a positive effect to the market. Competition improves market efficiency, which translates into lower prices for goods and services. Competition forces firms to enhance their productivity, ingenuity, and responsiveness to compete for consumers (Philippine Competition Commission, 2017).

\section{Conclusion}

There was a significant effect on the automotive industry in the Philippines brought by the implementation of the TRAIN law. It was found out that the total unit sales of the five (5) selected car manufacturers in Metro Manila have decreased during the year of implementation of the additional automotive tax compared to their sales prior to the year of its actual implementation. These car manufacturers have also adjusted their retail price necessitated by the TRAIN law, which also posed an effect to their total sales. Additionally, majority of the car manufacturers reported that when their retail price was changed, their total unit sales also decreased. Moreover, the aspect of competition between the leading car manufacturers in the country was also taken into account. It was found out that there was a high level of competition among car companies, more so when TRAIN law was implemented.

\section{Funding}

This study received no funding. 


\section{Conflict of Interests}

The authors declare no conflict of interest in this study.

\section{References}

Afif, M., Razak, A., \& Nayan, S. (2020). The price of customer satisfaction. Journal of Undergraduate Social Science and Technology, 2(2). http://abrn.asia/ojs/index.php/JUSST/article/view/78

Aldaba, R. M. (2003). Regulatory policies and reforms in the power and downstream oil industries (No. 2003-16). PIDS Discussion Paper Series. https://www.econstor.eu/handle/10419/127816

Aldaba, R. M. (2007). Assessing the Competitiveness of the Philippine Auto Parts Industry. Philippine Institute for Development Studies (PIDS). https://dirp3.pids.gov.ph/ris/dps/pidsdps0714.pdf

Aldaba, R. M. (2008). Assessing Competition in Philippine Markets. Philippine Institute for Development Studies (PIDS). https://www.econstor.eu/handle/10419/126748

Amirul, M., Islaini, A., \& Nayan, S. (2020). The Role of Price in the Marketing Mix. Journal of Undergraduate Social Science and Technology, 2(2), 1-3. https://ejmcm.com/article_4280_5256d61cc50efb3a4d01d9a7caa5bb57.pdf

AutoDeal. (2018). Philippine Automotive Industry Report 2018. AutoDeal. https://www.autodeal.com.ph/custom/pdf_report/PhilippineAutomotiveReport\% 20-\%20IndustryInsights2018.pdf

Azahari, A., \& Nayan, S. (2020). Role of trust towards business success. Journal of Undergraduate Social Science and Technology, 2(2). http://abrn.asia/ojs/index.php/JUSST/article/view/65

Cahiles-Magkilat, B. (2019). TRAIN law caused 16\% drop in auto sales in 2018. Manila Bulletin. https://mb.com.ph/2019/01/14/train-law-caused-16-drop-in-autosales-in-2018/

Carmudi Philippines. (2016). The Changing Landscape of the Vehicle Industry in Asia: Automotive Search Preferences in the Philippines 2014 - 2016. Carmudi. https://www.carmudi.com.ph/journal/changing-landscape-car-industry-asiaautomotive-search-preferences-philippines-2014-2016/

Castillo, C., Clarete, R., Muyrong, M., Tuano, P. (2019). Effects of TRAIN Excise Taxes on Goods and Prices. Philippine Institute for Development Studies (PIDS). https://www.pids.gov.ph/publications/6900

Conazo, A. (2018). The car buyers' behaviour. Business World. https://www.bworldonline.com/the-car-buyers-behavior/

Crismundo, K. (2019). Domestic carmakes sales down 16\% in 2018. https://www.pna.gov.ph/articles/1058859

Danao, R. (2018). TRAIN and Car Sales. PWC. https://www.pwc.com/ph/en/pwcneedles-in-a-haystack/train-and-car-sales.html

Department of Finance. (2018). https://www.dof.gov.ph/ra-10963-train-law-and-vetomessage-of-the-president/.

Dizon, R. (2021). Tax Incidence of Philippine Tax Reform: Poverty and Distributional Effect. Journal of Asian Finance Economics And Business, 8(2). https://doi.org/10.13106/jafeb.2021.vol8.no2.0281 
Ebrahim, A., Mojares, E., \& Montes, R. (2020). The Impact of Tax Reform for Acceleration and Inclusion (TRAIN) Law on Poor Income Class Families: A Phenomenological Study. Preprints. https://doi.org/10.35542/osf.io/k2n6r

Government of the Philippines. (2015). Executive Order No. 182: Providing for a Comprehensive Automotive Resurgence Strategy Program. http://www.gov.ph/2015/05/29/executive-order-no-182-s-2015/

Hennessy, H., \& Tol, R. S. (2011). The impact of tax reform on new car purchases in Ireland. Energy Policy, 39(11),

7059-7067. https://doi.org/10.1016/j.enpol.2011.08.011

International Trade Administration. (2020). Philippines Automotive Market. https://www.trade.gov/market-intelligence/philippines-automotive-market

Izarul, S., Syed, H., \& Nayan, S. (2020). WOW Your Customers : Tips to Retain Customers. Journal of Undergraduate Social Science and Technology, 2(2), 2-5. http://www.abrn.asia/ojs/index.php/JUSST/article/view/75

Jamaluddin, N. F. B., \& Esa, S. A. (2020). Effect of Price on Sales Volume. Journal of Undergraduate Social Science and Technology, 2(2). https://www.abrn.asia/ojs/index.php/JUSST/article/view/88

Jimeno, K. (2018). Tracking car prices under TRAIN Law. Philstar Global. https://www.philstar.com/business/motoring/2018/03/07/1794151/trackingcar-prices-under-train-law

Kaiser, K., Bredenkamp, C., \& Iglesias, R. (2016). Sin Tax Reform in the Philippines: Transforming Public Finance, Health, and Governance for More Inclusive Development. https://doi.org/10.1596/978-1-4648-0806-7

National Tax Research Center. (2018). Tax Changes You Need to know Republic Act 10963. Department of Finance.

Nkomo, T. (2019). Analysis of Toyota Motor Corporation. http://dspace.vnbrims.org:13000/jspui/bitstream/123456789/2458/1/Toyota\% 20Case\%20study.pdf

Ofreneo, Rene. (2016). Auto and Car Parts Production: Can the Philippines Catch Up with Asia?. Asia Pacific Business Review, 22(1), 48-64. http://www.tandfonline.com/doi/pdf/10.1080/13602381.2014.990212

Philippine Competition Commission. (2017). Rules of Procedure of Philippine Competition Commission. https://www.phcc.gov.ph/wpcontent/uploads/2017/09/2017-PCC-RULES-OF-PROCEDURE_CKMO.pdf

Pornelos, V. (2017). Excise Tax Simulation: How expensive will the cars of 2018 be? https://www.autoindustriya.com/features/excise-tax-simulation-how-expensivewill-the-cars-of-2018-be.html

Reside, R., \& Burns, L. (2021). Comprehensive tax reform in the Philippines: Principles, history, and recommendations. https://www.econstor.eu/handle/10419/162636.

Robles, R. (2019). Weathering the Storm: Toyota Philippines Sales Figures with the TRAIN Law. https://manilastandard.net/wheels-more-motoringquarterly/motoring- plus/303673/weathering-the-storm-toyota-philippinessales-figures-with-the-train-law.html

Rosli, N., \& Nayan, S. (2020). Why Customer First? Journal of Undergraduate Social Science and Technology, 2(2), 2018-2021. http://www.abrn.asia/ojs/index.php/JUSST/article/view/87

Ruzanna, A., Baharin, K., \& Nayan, S. (2020). Make a customer , not a sale : Review on customer trust. Journal of Undergraduate Social Science and Technology, 2(2), 2015-2019. http://www.abrn.asia/ojs/index.php/JUSST/article/view/66 
Sanchez, M. (2020). Vehicle sales volume in the Philippines 2012-2017. https://www.statista.com/statistics/909201/philippines-sales-volume-ofvehicles/\#statisticContainer

Sturgeon, T., Daly, J., Frederick, S., Bamber, P., \& Gereffi, G. (2016). The Philippines in the Automotive Global Value Chain. http://industry.gov.ph/wpcontent/uploads/2017/08/The-Philippines-in-the-Automotive-Global-ValueChain.pdf

Tai, W. (2016). The political economy of the automobile industry in ASEAN: a crosscountry comparison. Journal of ASEAN Studies, 4(1). https://nbnresolving.org/urn:nbn:de:0168-ssoar-6

Xi, C., \& Yun, W. (2015). The impact of tax policy stimulus on automobile choiceEvidence from Chinese automobile industry. African Journal of Business Management, 9(1), 1-7. https://doi.org/10.5897/AJBM2014.7346

Yussoff, N. M., \& Nayan, S. (2020). Review on customer satisfaction. Journal of Undergraduate Social Science and Technology, 2(2). http://www.abrn.asia/ojs/index.php/JUSST/article/view/80

Zamry, A. D., \& Nayan, S. M. (2020). What is the relationship between trust and customer satisfaction?.Journal of undergraduate social science and technology,2(2). http://abrn.asia/ojs/index.php/JUSST/article/view/76 